\author{
LEONID ORSHANSKYI \\ Drohobych Ivan Franko State Pedagogical University \\ http://orcid.org/0000-0001-9197-2953
}

\title{
ORIENTATION OF FUTURE TEACHERS TOWARDS HUMANISTIC AND PROFESSIONAL VALUES
}

\begin{abstract}
At present, the problems concerning the formation of values of future teachers are becoming increasingly important. Humanistic and professional values play a critical role in shaping the personality of a professional teacher, serve as the highest level of regulation of his conduct, determine the direction of his interests and needs, determine the inherent setup and motivation in the field of vocational and educational activities.

In retrospect, manifestation of humanistic and formation of professional values as internal guidelines relied upon by a teacher in his activities is associated with the development of the teaching profession. Therefore, the values, especially professional, do not remain unchanged in the process of development, they transform depending on the historical era: fade away losing their relevance, leading to changes in their hierarchy with the emergence of new values. On the basis of empirical studies, there was made an attempt to characterize the socio-demographic differences of subjects choice of occupation, to reveal the dynamics and features of influence of various social factors on the formation of humanistic and professional values of future teachers with respect to socio-economic changes in modern Ukraine.
\end{abstract}

Keywords: humanistic values, professional values, future teachers of higher pedagogical educational institutions

Educational paradigm, the widespread use of new information technologies, application of innovative forms and methods of training - all this has a significant impact on the educational process in a pedagogical higher education institution. The training based on the traditional paradigm is now becoming ineffective in terms of achieving a higher level of professional skill of the teachers who will soon be working in the new Ukrainian school. Successful implementation of pedagogical activity of the future teachers does not only require a certain set of theoretical knowledge and practical skills received at a university but also the existing system of humanistic and professional values, understanding the essence of pedagogical 
activity and readiness for a professional, competent entry into the modern market of educational services.

Many scholars (G. Vasyanovych, O. Vishnevskyi, V. Griniova, V. Ilyin, I. Isaev, M. Kagan, N. Mikhalchenko, O. Nevmerzhytska, M. Pidlisnyi, Y. Pelekh, M. Rokeach, M. Savchyn, V. Slastenin, G. Chizhakova and others) carried out the analysis of various aspects of the theory of values, forming its categorical apparatus, development of theoretical-methodological and psycho-pedagogical bases of formation of value orientations and behavior of an individual. The analysis of the concept of a value has shown that the majority of scholars determine its content through the selection of characteristics, or otherwise characteristic forms of social consciousness. For example, O. Vishnevskyi considers values as "a certain hierarchical system of ideals, purposes and fundamentals in which that society lives and whose implementation is perceives as the meaning of its existence" (Vishnevskyi 2003, p. 197). M. Rokeach defines value as "a persistent preference for a certain way of conduct, as opposed to another type of behavior or condition" (Rokeach 1973, p. 14).

Scientific studies provide a basis to identify the following approaches to disclosing the essence of value:

1) value is used for evaluation of objects and phenomena that meet any need, and is regarded as an objective quality of the object, due to its nature, it exists independently of humans and their practical activity;

2) value is equated with those phenomena of nature and society that are useful, necessary for people, or historically identify particular society or a class;

3) value reduced to the designation of the proper, desired, when it is ideal in social activities, is the essence of personal activities;

4) value is identified with the significance of one phenomenon for another, when any natural or social phenomenon is the object and subject of such relationships;

5) value is used to indicate the positive relevance of various objects and actions, events or parties and properties.

Summarizing the results of the epistemological analysis of the concept of value, we should note that it combines three aspects of its meaning: 1) characteristics of external properties of things, 2) psychological qualities of a personality, 3) the relationship between people, their communication. Here, a value is the most important component of the internal culture of a human which, expressed in personal settings, properties and qualities, defines the attitude to society, nature, other people, himself.

The basis of the axiological approach in professional training of future teachers are professional values. According to V. Slastenin and G. Chizhakova, professional 
values are guidelines, personal installations, the properties and qualities on the basis of which a person selects, develops and performs professional activity (Slastenin, Chizhakova 2003, p. 165). Forming the core of professional identity, professional values reflect the subjective attitude of people to the future profession and are essential for their self-development and self-realization. Scholars have identified a group of professional values, which, creating each other, form the axiological model containing terminal (values-goals) and instrumental values (values-means), which, in turn, are divided into values-relationship, values-quality and values-knowledge.

The problem of formation and development of professional values is currently becoming increasingly important because they play a vital role in shaping the personality of a future teacher; advocate a higher degree of regulation of his behavior, expressing the orientation of interests and needs; determine the inherent setup and motivation in the field of teaching. However, according to Vishnevskyi, in addition to purely professional, teachers first need to cultivate humanistic values, namely the absolute eternal values; basic national values; the basic civic values; the value of family life; environmental values (Vishnevskyi 2003).

Based on empirical research, the author has attempted to determine the effect of various factors on future teachers' education of humanistic and formation of professional values.

\section{SOCIAL EXPECTATIONS OF UNIVERSITY STUDENTS}

Within the understanding of the students as the most important social resource, the problem of formation of their humanistic and professional values has been and remains most relevant. The results of the study give reason to describe sociodemographic differences in the subjects' professional choice, to reveal the dynamics and features of influence of various social factors on the formation of professional strategies and value orientations of the university students with respect to socioeconomic changes in the modern Ukraine.

The study of humanistic and professional values of different social groups traditionally involves identifying the structure and dynamics of value priorities, factors influencing the formation and change of values of the subjects as well as identification of their social well-being. Social well-being is closely associated with the presence and resolution of social problems and social expectations, social setting, and sense of life. There is a close connection between the individual's ability to design their own future in accordance with the set of leading values, willingness to act following them, and the emotional response, feeling, evaluation of the causes of its past, present and future: a sense of satisfaction or dissatisfaction, one's own 
importance, optimism or pessimism, confidence in or uncertainty about their own ability and social situation.

In this context, we have studied the prospects of development of Ukrainian society as an indicator of the attitudes and expectations of modern students, that is, it was important for us to find out the way the socio-economic situation in the country affected the students' professional expectations; how students assess the prospects of development of the Ukrainian education and society, etc. In order to do so, we have conducted a diagnostic study at Drohobych Ivan Franko State Pedagogical University with 350 second-, third-, and fourth-year students.

In the first phase of this study, students' responses to the questionnaire helped to clarify the dynamics of their social expectations (Table 1).

Table 1. The dynamics of the social expectations of students (\%)

\begin{tabular}{|c|c|c|c|}
\hline Meaning & 2015 & 2016 & 2017 \\
\hline $\begin{array}{l}\text { I hope that in the near future, the socio-economic situation in Ukraine will } \\
\text { change for the better }\end{array}$ & 26 & 25 & 18 \\
\hline I believe that improvements will occur, but not very soon & 31 & 24 & 21 \\
\hline It is best to live for today and not to worry about the future & 16 & 21 & 22 \\
\hline I do not even hope for any significant changes & 14 & 12 & 18 \\
\hline I fear that life will continue to deteriorate & 7 & 8 & 8 \\
\hline I do not believe in rapid changes, but I am willing to do it & 3 & 5 & 6 \\
\hline I am already tired of waiting for a change, tired of unfulfilled expectations & 3 & 5 & 7 \\
\hline
\end{tabular}

Source: Author's own study.

The results in Table 1 show that only one out of four respondents is optimistic enough to believe that in the near future the situation in the country will improve despite the problems related to the socio-economic crisis. There is a strong tendency of reducing the number of the so-called cautious optimists - the ones who are confident even in the long term, however, this percentage has been steadily declining. At the same time, there are more of those who demonstrate the psychology of "nowism" - "we must live only for today". It is very likely that for one third of the students it is the only way to survive in difficult conditions of the modern socio-economic transformations.

\section{STUDENTS' VALUE ORIENTATIONS}

The next step was to determine the influence of social expectations and well-being of students on their value consciousness, that is, the objective was to study the content of value orientations regarding the purpose of life and means to achieve 
these goals. This was done using the technique of studying value orientations of Rokeach based on the direct ranking of the list of values. The first group was the terminal values (values-goals) that characterize vital targets, reveal the general orientation of behavior on the basis of the formation of vital goals of the main spheres of self-realization; the second group - instrumental values (values-means), which reflect perceptions of acceptable, possible means of achieving the vital goals.

The advantage of Rokeach's method is in its versatility, convenience and economy in the conduct of the survey and simplicity of processing of the results. Students were asked to determine the rank position of each of the proposed values. By counting the arithmetical mean, each value was given the ranking place in general (Table 2).

Table 2. Content of the students' value orientations

\begin{tabular}{|c|l|c|l|}
\hline Rank & \multicolumn{1}{|c|}{ Terminal values } & Rank & \multicolumn{1}{|c|}{ Instrumental values } \\
\hline 1 & Health & 1 & Good manners \\
\hline 2 & Financial security & 2 & Education \\
\hline 3 & The presence of true friends & 4 & Responsibility \\
\hline 4 & Love & 5 & Honesty \\
\hline 5 & Confidence & 3 & Independence \\
\hline 6 & Happy family life & 8 & Cheerfulness \\
\hline 7 & Interesting job & 6 & Self-control \\
\hline 8 & Freedom & 7 & Courage in defending one's own views \\
\hline 9 & Active life & 9 & Diligence \\
\hline 10 & Productive life & 10 & Tolerance \\
\hline 11 & Life wisdom & 11 & Strong will \\
\hline 12 & Entertainments & 17 & Broad worldview \\
\hline 13 & Personal development & 12 & Accuracy \\
\hline 14 & Cognitive ability & 13 & Effectiveness in resolving issues \\
\hline 15 & Public recognition & 14 & Rationality \\
\hline 16 & Beauty of nature, art & 15 & Responsiveness \\
\hline 17 & Creativity & 16 & Intransigence in terms of shortcomings \\
\hline 18 & Happiness of others & 18 & High demands \\
\hline
\end{tabular}

Source: Author's own study.

The analysis of the terminal values showed that majority of the students (over $60 \%)$ put health in the first place. And even those who prioritized other values, gave health a high place: $2^{\text {nd }}-4^{\text {th }}$, lowest $-8^{\text {th }}$. It should be noted that such unanimity was not observed in relation to other values. Students gave a high place to material security of life. Approximately $40 \%$ of the respondents mentioned it 
among the first 5 values; in the answers of other students, this value never fell below $10^{\text {th }}$ place. There was no big difference in the responses of boys and girls. In our opinion, it is interesting to see the attitude of students to a happy family life. The answers of the girls showed a relative unanimity - from $3^{\text {rd }}$ to $7^{\text {th }}$ place, whereas the boys' answers showed a major divergence (from $4^{\text {th }}$ to $14^{\text {th }}$ place).

The greatest divergence of views was observed in the ranking $\left(1^{\text {st }}\right.$ to $\left.18^{\text {th }}\right)$ of such values as life wisdom and confidence. Unfortunately, such values as creativity, cognition, development, which reflect the highest spiritual needs of a person, were given a low position by the majority of students. However, in our opinion, the most surprising thing was that the future teachers put the happiness of others in the last place of all the terminal values. In addition, no student included this value in the top ten.

In relation to instrumental values, there is the students' thinking about the individual values which, however, rarely coincide. Maybe except for high demands, which take one of the last places in the list. In our opinion, the significant divergence is related to the previously formed students' personal qualities and their past experience. Definitely positive is the fact that the first two places in the list are occupied by good manners and education. Although, not much unanimity was observed here either. Good manners have been ranked from $1^{\text {st }}$ to $13^{\text {th }}$ place and education - from $1^{\text {st }}$ to $16^{\text {th }}$. Unfortunately, responsiveness has been given a very modest position (from $9^{\text {th }}$ to $17^{\text {th }}$ ) by the future teachers which makes you wonder about the choice of their profession.

Analysis of the obtained data allowed one to draw some preliminary conclusions: the value orientations of future teachers are mostly moral in nature; most students have already formed a certain ideal, close to the standard. However, one third of the respondents has given preference to only one area of life - either family or career. Along with the value of health, the value of wealth is also a leading category. However, the recognition of health as a leading value does not always correlate with the practical implementation of the guidelines of healthy lifestyle on the activity-behavioral level. The core of value consciousness of young people consists of the three main values - money, friends, job, the significance of which is confirmed by almost every third respondent. Serious concern is the fact that the values of the selected future teachers mainly focus on satisfaction of their own needs, and not the needs of others.

Despite the relative decline in the share of communicative values, their rankorder position is quite stable, due to the age specificity of students as a social group. For young people, friends are a primary reference group. However, the process of self-identification of students is not only linked with the search of a reference group, or raising their own families, but primarily with the profession, search for 
an interesting job. Although the orientation towards an interesting job is not correlated with a relatively high significance of such values of education, diligence, efficiency, etc.

As noted above, it is not sufficient to form a certain amount of professional knowledge, skills and competencies in students, it is important to teach them how to skillfully enrich the core values and put them into practice. The students should form a certain system of professional values, based on which they will be able to use their knowledge, skills, competencies for the benefit of family, country and the world in general. Otherwise, there might be a

(...) risk to educate professional cynics or even criminals who may become a threat to humanity. After all, it should be noted that heading for the goal, people who do not have clear spiritual values, can use any means, guided by the slogan "the end justifies the means". Therefore, "the value vaccination" must be an integral element of modern education. But for the efficiency of "value vaccination" the educators must have a good understanding of the nature of values, their varieties, hierarchy, and means of inculcation (Pelekh 2009, p. 36).

\section{ORIENTATION OF FUTURE TEACHERS TOWARDS PROFESSIONAL VALUES}

In the second stage of the diagnostic study, we examined orientation of students towards professional values. To explore different components of value orientations, we used several methods. In particular, for the study of professional intentions we have undertaken a students' survey. They were asked to answer the following questions:

1. If you could choose a profession, would you choose the profession of a teacher?

2. Are you satisfied with the chosen pedagogical higher educational institution?

3. How well do you study?

4. After completion of training, what professional and life path will you choose?

5. What kind of job would you like to receive?

The students' answers to the first question of the questionnaire were distributed as follows: "Yes" - 27\%; "No" - 39\%, "I don't know" - 36\%. That means that only every fourth student is sure of the right professional choice. However, even those who were negative in their choice, continue to study at Drohobych Ivan Franko State Pedagogical University. The responses of boys and girls have been compared (Table 3). 
Table 3. The confidence of students in choosing teaching profession (\%)

\begin{tabular}{|l|c|c|}
\hline \multicolumn{1}{|c|}{ Answers } & Boys & Girls \\
\hline Yes & 21 & 33 \\
\hline No & 42 & 36 \\
\hline I don't know & 37 & 31 \\
\hline
\end{tabular}

Source: Author's own study.

From these data, we can conclude that the number of boys and girls who are hesitant about their attitude to the choice of the teaching profession is different by a third, i.e. the girls are more confident in the correctness of their professional choice. At the same time, these survey results are the reason for concern and indicate a low level of career guidance.

As regards satisfaction with the selected institution of higher education the students' answers are as follows: "Quite satisfied" - 26\%; "Yes, partially" - 49\%; "No" - 25\%. The next question related to academic achievements. We obtained the following answers: "Excellent academic performance" - 7\%; "Excellent and good" - 32\%; "Good and satisfactory" - 31\%; "Satisfactory" - 23\%; "Basically underperform" - 7\%. It should be noted that there was no correlation between these two answers. Accordingly, among the ones who are "satisfied" with institution of higher education are students with different performance level - "excellent", "satisfactory" and even those who "underperform". Among the "dissatisfied" ones there are also the students with different levels of educational achievements. This suggests that the academic performance - marks for test and examination sessions -is not the main factor influencing satisfaction or dissatisfaction of the students with their educational progress and choice of educational institutions.

We have also analyzed the answers to the question about future life plans separately for boys and girls. The responses of girls represent such a hierarchy of variants of the prevailing way of life: 1) good job - 29\%, 2) happy marriage - 22\%, 3) continued education in a different specialty - 17\%, 4) search for a well-paid job not related to pedagogical field $-13 \%, 5$ ) having their own business $-11 \%, 6)$ other plans $-8 \%$. The boys' responses showed a slightly different impression: 1) search for a well-paid job not related to pedagogy $-39 \%, 2$ ) running their own business $-27 \%, 3$ ) continued education in a different specialty $-13 \%$, 4) good job $-11 \%, 5)$ other plans $-10 \%$. In relation to other plans, the majority of students did not want to specify their responses, but in some questionnaires and during interviews, the following predominant motives were discovered: to move abroad, work abroad and return, continue education abroad, etc. The answers to the question about the preferred job give the opportunity to see their attitude towards teaching profession as a whole (Table 4). 
Table 4 . The attitude of students towards the desired future work (\%)

\begin{tabular}{|l|c|}
\hline \multicolumn{1}{|c|}{ The criteria for the desired job } & Indicators \\
\hline High wages without much effort, physical and mental strength & 47 \\
\hline A job at school, according to their profession & 26 \\
\hline The work of creative, exploratory nature associated with the art or science & 12 \\
\hline Any (including non-prestige) high-paying job & 11 \\
\hline Work at school in a managerial position & 4 \\
\hline
\end{tabular}

Source: Author's own study.

The results of the survey show that the vast majority of students strive to receive higher salaries without making any extra effort to do so. Unfortunately, only a quarter of the interviewed students showed interest in working at school - their chosen pedagogical specialty. The strange thing is that work in senior positions is desirable for a small number of students, which is in the range of statistical error. This is probably due to the fact that school administrators shoulder the greater responsibility not only for themselves but also for the other teachers' work as well as academic performance of school pupils.

Summarizing the results of the survey, it can be stated that the majority of students are focused on material values, work for them is not an internal necessity, but only a means to earn money. And even those who want to pursue a teaching career, mainly choose the teaching profession guided by the fact that it is "a clean and intellectual job", which "does not require much effort", etc.

To identify the motives for a professional choice, we used K. Zamfir's method - motivation of professional activity in modification by A. Rean. This method is based on the theory of intrinsic and extrinsic motivation which helps to determine the motivational complex of a personality, the nature of correlation between the three types of motivation: internal, external positive and external negative. This complex shows the general thrust of students' professional motivation.

The analysis and interpretation of empirical data indicate that there are no significant differences in motivation orientation in the professional pedagogical activity among male and female students. Analyzing the diagnostic results for the whole sample of respondents, we can conclude that only a quarter of the students are focused directly on the teaching profession, which they get at a pedagogical university. About $68 \%$ of students have found the instability of professional motivation, that is, were not sure of the correctness of their choice, and 7\% of respondents showed a very low level of motivation in relation to the chosen future teaching profession.

Today, the structure of educational values is undergoing significant transformations. This is due to the democratic changes, new social requirements, informati- 
zation and humanization of the modern domestic pedagogical education. Based on the analysis of literary sources, we have distributed humanistic and professional values in the following groups: 1) values-goals - values which reveal the significance and meaning of the objectives of pedagogical activity of the teacher, 2) values-tools - values which reveal the importance of the ways and means of implementing the educational activities of teachers, 3) values-relations - values which reveal the value and meaning of relationships as the main mechanism of functioning of complete educational activities, 4) values-knowledge - values which reveal the significance and meaning of psychological and pedagogical knowledge in the implementation of educational activities, 5) values-quality - values which reveal the significance and meaning of the qualities of a teacher's personality, that is, the multiplicity of interrelated individual, personal, communicative, professional qualities of a teacher's personality as a subject of pedagogical activity.

Research on orientations towards humanistic and professional values has given the opportunity to fix the expression of social expectations of university students. The basis of value consciousness of young people consists of such leading values as health, family, friends, work, etc. At the same time, the pursuit of material wealth, the desire to start a business, etc. is more situational. Assessing the professional intentions of the students, we have identified the following important points: the increase in the level of anxiety for their future and the lack of continuation of the dominant orientations towards work in their chosen teaching specialty. In this context, it should be stressed that value orientations and life strategies of modern students depend primarily on the choice of a future profession (and, thus, a university), which can be done after finishing school purposefully and rationally or spontaneously, that is, accidentally under the influence of external causes and factors. The latter depends on the global and local trends of development of Ukrainian higher pedagogical education, which is on the verge of radical changes in terms of the methodological and institutional aspects.

\section{REFERENCES}

Вишневський, O.I., 2003, Теоретичні основи сучасної української педагогіки. Дрогобич: Коло.

Пелех, Ю.В., 2009, Ціннісно-смисловий концепт професійної підготовки майбутнього педагога. Рівне: Тетіс.

Сластенин, В.А., Чижакова, Г.И., 2003, Введение в педагогическую аксиологию. Москва: Академия.

Rokeach, M., 1973, The Nature of Human Values. New York: Free Press. 


\title{
ORIENTACJA PRZYSZEYCH NAUCZYCIELI OPARTA NA WARTOŚCIACH HUMANISTYCZNYCH I ZAWODOWYCH
}

\begin{abstract}
Abstrakt: Problemy związane z tworzeniem wartości przez przyszłych nauczycieli obecnie stają się coraz ważniejsze. Wartości humanistyczne i zawodowe odgrywają kluczową rolę w kształtowaniu zawodowym osobowości nauczyciela, działają jako wyższy poziom regulacji jego zachowania, określają kierunek jego zainteresowań i potrzeb oraz właściwości jego nastawienia i motywacje w dziedzinie jego działalności zawodowej. W retrospektywie historycznej przejaw wartości humanistycznych oraz kształtowanie wartości zawodowych jako wewnętrznych drogowskazów, na które orientuje się nauczyciel w swej działalności, związany jest z powstaniem i rozwojem zawodu pedagogicznego. Wartości, zwłaszcza zawodowe, w trakcie swojego rozwoju podlegają transformacji - są przekształcane w zależności od okresu historycznego: zanikają, tracą swoją aktualność, powstają nowe wartości, zmienia się ich hierarchia. Na podstawie badań empirycznych podjęto próbę scharakteryzowania społeczno-demograficznych podmiotów wyboru zawodowego oraz określenia dynamiki i osobliwości wpływu różnych czynników socjalnych na kształtowanie wartości humanistycznych i zawodowych przyszłych pedagogów ze względu na zmiany socjalno-ekonomiczne mające miejsce we współczesnej Ukrainie.
\end{abstract}

Słowa kluczowe: wartości humanistyczne, wartości zawodowe, nauczyciele, szkoła wyższa 